\title{
Aplikasi Quality Function Deployment dalam Perancangan Sabun Mandi HerbalVirgin Coconut Oil
}

\author{
Indah Setiawati ${ }^{1)}$, Ardiansyah $^{2)}$, Ervina Mela Dewi ${ }^{2)}$ \\ ${ }^{1}$ Jurusan Sosial Ekonomi Pertanian, Fakultas Pertanian, Universitas Jenderal Soedirman \\ email: iindahs@unsoed.ac.id \\ ${ }^{2} J u r u s a n$ Teknologi Pertanian, Fakultas Pertanian, Universitas Jenderal Soedirman \\ email: ard@unsoed.ac.id \\ ${ }^{2}$ Jurusan Teknologi Pertanian, Fakultas Pertanian, Universitas Jenderal Soedirman \\ email: ervina.mela@unsoed.ac.id
}

\begin{abstract}
The purpose of this study is to determine the design of herbal bath soap derived VCO based on consumer priorities using Quality Function Deployment method. Information about consumer needs obtained from a survey of consumer herbal soap-based coconut oil. Surveys include open interviews to listen the quality attributes of consumer needs and distribution of consumer importance wieght assessment questionnaires, assessment of consumer satisfaction rate and appraisal of sales attractiveness. House of quality analysis on the QFD method helps the company make decisions in presenting VCO herbal bath soap products in the market. Efficacy of bath soap is the highest priority for consumers. In addition to antiseptic properties, the properties of moisturizing and able to remove dirt, soap consumers are expected to also include comfort (not cause irritation) and security (registered BPOM). Technical parameters with the highest priorities are the determination of oil materials. By developing bath soap products based on these highest priority, highest consumer satisfication can be reached.
\end{abstract}

Keywords: house of quality, herbal bathsoap, product design, QFD, VCO

\begin{abstract}
Abstrak
Tujuan penelitian ini adalah untuk merancang sabun mandi herbal turunan VCO berdasarkan prioritas konsumen dengan menggunakan analisis matriks perencanaan metode QFD. Informasi tentang keinginan konsumen diperoleh dari survei konsumen sabun herbal berbasis minyak kelapa. Survei meliputi wawancara terbuka untuk mendengarkan suara konsumen dan penyebaran kuesioner tertutup untuk memperoleh penilaian tingkat kepentingan, tingkat kepuasan dan daya tarik penjualan. Analisis rumah mutu pada metode QFD membantu perusahaan melakukan pengambilan keputusan dalam menyajikan produk sabun mandi herbal di pasar. Khasiat sabun mandi merupakan prioritas tertinggi bagi konsumen. Selain khasiat antikuman, khasiat melembabkan dan mampu mengangkat kotoran, sabun yang diharapkan konsumen juga meliputi kenyamanan (tidak menimbulkan iritasi) dan keamanan (terdaftar BPOM). Parameter teknis dengan prioritas tertinggi adalah penentuan bahan oli. Dengan mengembangkan produk sabun mandi berdasarkan prioritas tertinggi tersebut, kepuasan konsumen tertinggi dapat dicapai.
\end{abstract}

Keywords: rumah mutu, sabun mandi herbal, desain produk, QFD, VCO

\section{PENDAHULUAN}

Produk sabun mandi yang beredar di pasar makin beragam, baik dari segi merek, jenis, harga maupun variasi lain yang terkandung dalam produk tersebut (Sipahutar, et al., 2013). Kesadaran lingkungan dan kesadaran penampilan secara positif mempengaruhi 
minat beli produk herbal (Kim and Chung, 2011) memicu meningkatnya permintaan produk herbal dan telah banyak diproduksi produk personal care herbal termasuk sabun mandi (Duraisamy, et al., 2011; Fathima, et al., 2011).

Penambahan VCO menjadi sabun mandi herbal memberikan karakteristik yang sangat cocok untuk dikembangkan. Penggunaan VCO pada sabun mandi secara alami dapat berfungsi sebagai emmolient (Agero dan Veralo-Rowell, 2004; Setyoningrum, 2010; Kasor dan Sukmawati, 2015). Fungsi lain dari sabun VCO adalah sebagai antibakteri alami (Febriyenti et al., 2014; Widyasanti dan Hasna, 2016).

VCO juga merupakan komoditas yang potensial di Indonesia. Luas perkebunan kelapa Indonesia yang menduduki peringkat pertama dunia menjadikan peluang dalam pengembangan produk olahan kelapa termasuk VCO (Arancon, 2013). VCO umumnya dibuat sebagai produk siap minum dan dijual curah. Pengembangan produk olahan kelapa (VCO) menjadi produk non pangan yakni sabun mandi herbal diharapkan dapat mendukung estafet agroindustri kelapa yang memberikan nilai tambah lebih tinggi sebagaimana yang telah banyak dikembangkan di negara Thailand dan Filipina.

Salah satu strategi pemasaran produk adalah bagaimana menyampaikan produk sesuai keinginan konsumen (Gharakhani dan Eslami, 2012). Salah satu strategi pemasaran produk dengan mengakomodasi keinginan konsumen adalah dengan menggunakan metode quality function deployment (Akao, 2012). QFD mengkomunikasikan apa kebutuhan dan keinginan konsumen kemudian menerjemahkannya menjadi bagaimana uraian teknis proses produksi yang tepat (Jaiswal, 2012).

Tujuan penelitian ini adalah menentukan strategi pemasaran produk sabun mandi herbal turunan VCO menggunakan metode QFD dengan mengetahui (1) atribut mutu persyaratan konsumen dan spesifikasi desain produk sabun mandi, (2) prioritas atribut produk berdasarkan tingkat kepentingan, tingkat kepuasan, dan daya tarik penjualan melalui interpretasi matriks rumah mutu (house of quality).

\section{Lokasi dan Waktu Penelitian}

\section{METODE PENELITIAN}

Metode penelitian yang digunakan dalam penelitian ini adalah metode survei dengan mengambil lokasi di Kota Tegal. Pemilihan Kota Tegal dilakukan secara sengaja (purposive). Kota Tegal ditentukan sebagai tempat penelitian dikarenakan pertimbangan kemudahan dalam memperoleh responden dan merupakan salah satu daerah pemasaran produk. Selain itu, Kota Tegal merupakan salah satu kota yang memiliki struktur perekonomian yang dominan pada sektor perdagangan dan industri pengolahan. Masyarakat Kota Tegal merupakan salah satu konsumen yang potensial dilihat dari penduduknya yang berkembang, Indeks Pembangunan Manusia yang tergolong tinggi, pertumbuhan perumahan yang dibangun, dan pendapatan penduduk yang cukup tinggi (Badan Pusat Statistik Kota Tegal, 2016). Sedangkan waktu penelitian dilakukan pada bulan Januari - Juli 2017.

\section{Jenis dan Sumber Data}

Jenis data dalam penelitian ini adalah data primer dan sekunder. Data primer diperoleh dari kegiatan observasi, penyebaran kuesioner, dan wawancara kepada konsumen yaitu mencakup data responden pengguna sabun mandi, atribut persyaratan konsumen, spesifikasi desain produk, penilaian tingkat kepentingan konsumen, penilaian tingkat kepuasan konsumen dan daya tarik penjualan. Data primer lainnya dilakukan dengan wawancara pakar untuk menentukan parameter teknis pembuatan sabun mandi, korelasi hubungan antar parameter teknis, dan hubungan antara parameter teknis dengan 
atribut persyaratan konsumen. Data sekunder adalah hasil observasi literatur produkproduk sabun mandi turunan VCO yang diperoleh dari jurnal, buku, website, dan hasilhasil penelitian lainnya yang dipublikasikan dan berhubungan dengan penelitian ini.

\section{Penentuan Sampel}

Pengambilan sampel dilakukan dengan metode purposive sampling. Menurut Sugiyono (2008), purposive sample adalah teknik pengambilan sampel sumber data dengan pertimbangan tertentu yakni sumber data dianggap paling tahu tentang apa yang diharapkan, sehingga memudahan peneliti menjelajahi objek atau situasi sosial yang sedang diteliti. Responden pada penelitian ini adalah orang yang menggunakan sabun mandi herbal (natural soap) berbasis minyak kelapa, maksimal konsumsi 3 bulan yang lalu, dan usia minimal 15 tahun dengan asumsi sudah memiliki pilihan atas sabun mandi yang diinginkan. Izhar (2010) menyatakan bahwa usia tersebut pada umumnya seseorang akan lebih eksperimental, cenderung mencoba atau bergantiganti merek produk, lebih sadar akan penampilan dan mode.

Penentuan jumlah sampel menggunakan rumus Wibisono karena jumlah populasi keseluruhan tidak diketahui secara pasti (Salim, 2014; Andayani, et al., 2015). Penentuan jumlah sampel dilakukan melalui perhitungan berikut :

$$
\mathbf{n}=\frac{\mathbf{Z}(\alpha / 2)^{2}(\mathbf{p}(\mathbf{1}-\mathbf{p}))}{\mathbf{E}^{2}}
$$

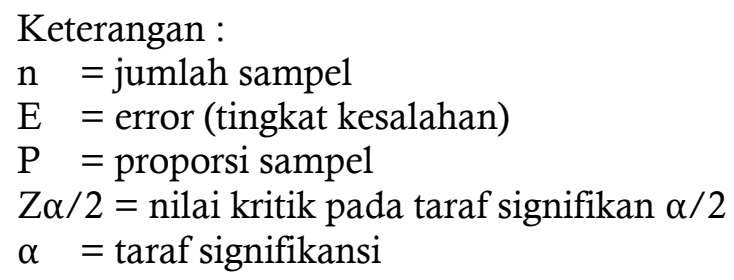

Oleh karena nilai populasi belum diketahui maka dicari dengan menggunakan rumus sebagai berikut :

$$
\begin{gathered}
\mathrm{F}(\mathrm{p})=\mathrm{p}(1-\mathrm{p}) \\
\mathrm{F}(\mathrm{p})=\mathrm{p}-\mathrm{p} 2 \\
d f(p) d(p)=1-2 \mathrm{p} \\
(\mathrm{df}(\mathrm{p})) /(\mathrm{d}(\mathrm{p})) \quad \begin{array}{c}
\text { maksimal jika }(\mathrm{df}(\mathrm{p})) /(\mathrm{d}(\mathrm{p}))=0, \text { maka } \\
0=1-2 \mathrm{p} \\
\mathrm{p}=0,5
\end{array}
\end{gathered}
$$

Apabila proporsi di dalam populasi yang tersedia tidak diketahui, maka nilai variansi $\mathrm{p}$ dapat diganti dengan nilai maksimum yaitu $0.5 \times 0.5=0.25$ (Walpole, 1992). Sehingga dengan tingkat kepercayaan 95\% dan kesalahan tidak lebih dari 5\%, maka z1/2 $\alpha=1.96$. Jumlah sampel minimal yang diambil :

$$
\begin{aligned}
\mathrm{n} & =\frac{\mathrm{z}(\alpha / 2)^{2}(\mathrm{p}(1-\mathrm{p}))}{\mathrm{E}^{2}} \\
& =\frac{1,96^{2}(0,25)}{0,5^{2}}=96,04
\end{aligned}
$$

Jadi, jumlah sampel yang harus dimbil minimal sebanyak 97 responden. Kuesioner utama yang disebarkan sebanyak 100 responden. 
Tahapan Penelitian dan Analisis Data

Tahapan penelitian dilakukan sebagai berikut.

1. Identifikasi atribut mutu persyaratan konsumen dan spesifikasi desain produk didapatkan dari hasil observasi produk dan wawancara konsumen (voice of consumer). Jumlah responden yang dilibatkan sebanyak 100 orang konsumen sabun mandi herbal berbasis minyak kelapa.

2. Uji validitas dan reliabilitas instrumen dilakukan pada 30 orang konsumen sabun mandi herbal berbasis minyak kelapa. Uji validitas dilakukan untuk mengetahui sejauh mana kuesioner dapat mengukur variabel yang akan diukur. Reliabilitas adalah suatu angka yang menunjukkan konsistensi suatu alat pengukur dalam mengukur gejala atau aspek yang sama. Uji validitas dilakukan dengan menghitung korelasi antara masing-masing pertanyaan dengan skor total menggunakan rumus teknik korelasi product moment yang dikemukakan oleh Karl Pearson (Sugiyono, 2008). Teknik yang digunakan pada uji reliabilitas adalah metode Cronbach's Alpha (Riduwan, 2004; Anastasiadou, 2011).

3. Menyusun tingkat kepentingan konsumen atau important weight (IW), tingkat kepuasan atau current point (CP), dan daya tarik penjualan atau sales point (SP) berdasarkan atribut mutu yang diperoleh dari voice of consumer.

4. Tahap interpretasi data dan analisis dilakukan dengan menggunakan House of Quality (Ficalora dan Cohen, 1995)

a. Menyusun tingkat kepentingan atribut kebutuhan konsumen (IW), tingkat kepuasan (CP), dan menyusun daya tarik penjualan (SP).

Rasio perbaikan dihitung dengan menggunakan rumus sebagai berikut:

$$
\mathrm{IR}=\frac{\text { Target yang diinginkan (goal) }}{\text { Kepuasan konsumen saat ini (current point) }}
$$

b. Menghitung nilai bobot keseluruhan untuk persyaratan konsumen (consumer absolute weight) atau CAW dengan rumus:

CAW $=$ IW $x$ IR $x$ SP

Keterangan :

CAW (consumer absolute weight $)=$ Total nilai bobot

IW (Important Weight) = Tingkat Kepentingan Konsumen

IR (Improvement Ratio) = Rasio peningkatan

$\mathrm{SP}$ (sales point) = daya tarik pen jualan

c. Menentukan prioritas (rank) yang ditentukan dengan mengurutkan perbandingan bobot keinginan konsumen (consumer needs weight) menunjukkan seberapa besar masing-masing atribut dapat memenuhi keinginan konsumen.

\section{HASIL DAN PEMBAHASAN \\ Identifikasi Atribut Mutu dan Spesifikasi Desain Produk}

Produk sabun mandi yang akan dirancang dengan menggunakan metode quality function deployment (QFD) ditentukan dengan pengamatan langsung di masyarakat, yaitu memilih jenis produk yang paling banyak dipilih oleh konsumen di pasaran (Andayani, et al. 2015). Berdasarkan pengamatan langsung terhadap 100 responden yang dilakukan di toko-toko swalayan diketahui bahwa jenis produk sabun mandi yang sering dipilih adalah sabun mandi padat (opaque soap), sabun mandi cair (liquid soap), dan sabun mandi 
JTS : Jurnal Teknik

P-ISSN: 2302-8734

E-ISSN: 2581-0006

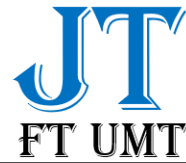

Vol. 9 No. 2 Th. 2020

Halaman : $44-53$

Desember 2020

transparan (transparant soap). Jenis sabun mandi yang paling banyak dipilih adalah sabun mandi padat (opaque soap). Alasan dalam pemilihan produk sabun mandi padat (opaque soap) tersebut karena dianggap lebih murah dan hemat, awet, mampu menjaga kesehatan kulit, dan lebih kesat. Observasi juga dilakukan pada sabun mandi herbal berbasis minyak kelapa dan yang banyak dipilih adalah sabun sereh, sabun susu, dan sabun zaitun dengan merek "Herborist" dan "Mustika ratu".

Penyebaran kuesioner atribut persyaratan konsumen bertujuan untuk mendapatkan informasi berupa kata atau kalimat dari responden yang kemudian akan diterjemahkan menjadi atribut suara konsumen (voice of consumer atau VoC). VoC disajikan dalam Tabel 1.

Tabel 1 Atribut mutu persyaratan konsumen

Atribut Suara Konsumen

Tingkat kewangian (wangi tahan lama; wangi saat digunakan; tidak wangi)

Aroma parfum (lemon; mawar; sereh; dan menthol)

Tekstur (padat/tidak lembek)

Ukuran (besar; sedang; dan kecil)

Bentuk sabun (oval; persegi panjang; kotak)

Busa (keluar banyak dalam 1-5x gosok)

Kesat (mudah dibilas)

Tidak menimbulkan iritasi kulit

Kandungan tambahan (Susu; Madu; Zaitun; Vitamin)

Berkhasiat mengangkat kotoran

Berkhasiat membunuh kuman/antibakteri

Berkhasiat menjaga kelembaban kulit

Berkhasiat membantu mencerahkan kulit

Bahan kemasan (kertas; plastik; artpapper; dan kombinasi dus-plastik)

Desain kemasan menarik

Mencantumkan registrasi BPOM

Mencantumkan registrasi halal MUI

Mencantumkan komposisi

Mencantumkan netto

Harga satuan (Rp3.000, Rp5.000-Rp 10.000, dan 20.000)

Sumber: Data diolah, 2017

Spesifikasi desain produk bertujuan untuk mendapatkan informasi mengenai desain dasar produk sabun mandi padat yang akan dihasilkan (Andayani, et al., 2015). Atribut mutu yang memiliki beberapa alternatif yakni pada atribut tingkat kewangian, aroma parfum, ukuran, bentuk, kandungan tambahan, bahan kemasan, dan harga, perlu ditetapkan mana alternatif yang dipilih oleh konsumen potensial (pengguna sabun mandi herbal berbasis minyak kelapa). Responden memilih atribut mutu alternatif untuk menjadi pertimbangan dalam menentukan desain produk. Rekapitulasi alternatif desain untuk masing-masing atribut persyaratan konsumen disajikan pada Tabel 2. 
JTS : Jurnal Teknik

P-ISSN: 2302-8734

E-ISSN: 2581-0006

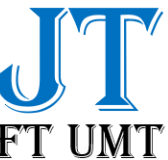

Vol. 9 No. 2 Th. 2020

Halaman : $44-53$

Desember 2020

Tabel 2 Rekapitulasi alternatif spesifikasi desain produk

\begin{tabular}{|c|c|c|c|}
\hline No & $\begin{array}{l}\text { Atribut } \\
\text { Mutu }\end{array}$ & Alternatif Desain & $\%$ \\
\hline \multirow{3}{*}{1.} & \multirow{3}{*}{$\begin{array}{l}\text { Tingkat } \\
\text { kewangian }\end{array}$} & a. Wangi tahan lama (dirasakan sepanjang hari) & 22 \\
\hline & & b. Wangi (dirasakan saat digunakan/saat mandi) & 78 \\
\hline & & c. Tidak wangi/tanpa parfum & 11 \\
\hline \multirow{4}{*}{2} & \multirow{4}{*}{$\begin{array}{l}\text { Aroma } \\
\text { Parfum }\end{array}$} & a. $\quad$ Lemon & 46 \\
\hline & & Mawar & 14 \\
\hline & & Sereh & 19 \\
\hline & & Menthol & 21 \\
\hline \multirow{3}{*}{3} & \multirow{3}{*}{ Ukuran } & a. Besar (>90gram) & 15 \\
\hline & & a. Sedang (80-90 gram) & 71 \\
\hline & & c. Kecil (<80 gram) & 14 \\
\hline \multirow{3}{*}{4} & \multirow{3}{*}{ Bentuk } & a. Oval & 51 \\
\hline & & b. Persegi panjang & 25 \\
\hline & & b. Kotak & 24 \\
\hline \multirow{4}{*}{5} & \multirow{4}{*}{$\begin{array}{l}\text { Jenis Bahan } \\
\text { Kemasan }\end{array}$} & a. Kertas (dus) & 22 \\
\hline & & b. plastik & 12 \\
\hline & & c. kertas glossy/art papper & 23 \\
\hline & & d. kombinasi dus dan plastik & 43 \\
\hline \multirow{4}{*}{6} & \multirow{4}{*}{$\begin{array}{l}\text { Kandungan } \\
\text { tambahan }\end{array}$} & a. Susu & 53 \\
\hline & & b. Madu & 12 \\
\hline & & c. Zaitun & 21 \\
\hline & & d. Vitamin & 23 \\
\hline \multirow{4}{*}{7} & \multirow{4}{*}{$\begin{array}{l}\text { Harga } \\
\text { (kemasan } \\
80-90 \text { gram) }\end{array}$} & a. di bawah Rp5.000 & 20 \\
\hline & & b. Rp5.000 s.d. Rp10.000 & 51 \\
\hline & & c. Rp10.001 s.d. Rp20.000 & 16 \\
\hline & & d. Lebih dari Rp20.000 & 12 \\
\hline
\end{tabular}

Sumber: Data diolah, 2017

Alternatif desain dipilih berdasarkan persentase tertinggi (Tabel 2). Alternatif atribut produk (tingkat kewangian, aroma parfum, bentuk, ukuran, busa, kandungan tambahan dan harga) yang telah dipilih kemudian digabungkan dengan atribut mutu lainnya yang sudah diperoleh dari VoC tahap pertama sehingga spesifikasi desain produk secara keseluruhan dapat ditentukan. Spesifikasi desain produk sabun mandi secara keseluruhan adalah wangi dirasakan saat digunakan, jenis parfum lemon, ukuran sedang (kemasan isi 80 - 90 gram), bentuk sabun oval, busa yang banyak (keluar dalam 1-5x gosok), kemasan kombinasi dus dan plastik, desain kemasan yang menarik, kesan kesat/mudah dibilas, tidak menimbulkan iritasi, tekstur padat (tidak lembek), mengandung susu, berkhasiat mengangkat kotoran, berkhasiat membunuh kuman, berkhasiat menjaga kelembaban kulit, berkhasiat membantu mencerahkan, bisa digunakan sebagai sabun muka, mencantumkan registrasi BPOM, mencantumkan komposisi bahan, mencantumkan berat bersih/netto, mencantumkan registrasi halal MUI, harga satuan Rp5.000,00 - Rp10.000,00 (kemasan isi 80-90 gram).

\section{Uji Validitas dan Reliabilitas Instrumen}

Pengujian ini dilakukan kepada 30 responden guna memastikan apakah kuesioner tingkat prioritas kepentingan, tingkat kepuasan, dan kuesioner daya tarik penjualan, valid dan reliabel. Hasil perhitungan uji validitas kuesioner menunjukkan seluruh atribut mutu dinyatakan valid karena nilai $\mathrm{r}$ hitung pada masing-masing atribut persyaratan konsumen 
JTS : Jurnal Teknik

P-ISSN: 2302-8734

E-ISSN: 2581-0006

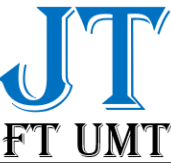

Vol. 9 No. 2 Th. 2020

Halaman : $44-53$

Desember 2020

tersebut lebih besar dibandingkan dengan nilai $r$ tabel $(0,36)$. Seluruh atribut mutu tersebut dapat dijadikan variabel pertanyaan dalam instrumen penelitian karena dapat mengukur apa yang ingin diukur. Atribut mutu persyaratan konsumen yang dinyatakan valid kemudian digunakan pada uji reliabilitas (Andayani, et al. 2015). Nilai reliabilitas instrumen $\left(\mathrm{r}_{11}\right)$ untuk kuesioner tingkat kepentingan, tingkat kepuasan, dan daya tarik penjualan masing-masing sebesar 0,882, 0,942, dan 0,869. Hasil uji reliabilitas menunjukkan bahwa $r_{11}$ dalam kuesioner lebih besar dari nilai $r$ tabel $(r$ tabel $=0,36)$ artinya instrumen yang digunakan layak menjadi alat yang dapat diuji pada waktu dan orang yang berbeda. Instrumen tersebut dapat digunakan secara berulang-ulang di lain waktu oleh siapa saja dengan menggunakan obyek yang sama maka akan menghasilkan hasil yang relatif sama (Riduwan, 2004; Anastasiadou, 2011).

\section{Rancangan dan Interpretasi House of Quality}

Rumah mutu (house of quality atau HoQ) tersusun dari tingkat kepentingan konsumen (importance weight), tingkat kepuasan (curent point), dan daya tarik penjualan (sales point) yang didapatkan dari hasil kuesioner. Skema rumah mutu untuk rancangan produk sabun mandi herbal disajikan pada Gambar 1.

Perancangan produk dilakukan berdasarkan hasil analisis rumah mutu (Andayani, et al., 2014). Berdasarkan analisis rumah mutu, atribut yang akan dirancang tergolong menjadi 19 tingkat prioritas berdasarkan bobot keinginan konsumen (dua atribut memiliki nilai bobot yang sama). Kolom bobot keinginan konsumen (consumer needs weight) menunjukkan seberapa besar masing-masing atribut dapat memenuhi keinginan konsumen (Gharakhani dan Eslami, 2012). Gambar 1 menunjukkan bahwa atribut berkhasiat mampu membunuh kuman/antibakteri memiliki bobot tertinggi yaitu sebesar $6,17 \%$. Atribut bentuk oval memiliki bobot terendah yaitu sebesar 3,25\%. Sehingga dapat disimpulkan dengan merancang produk sabun mandi dengan memperhatikan atribut sabun yang berkhasiat mampu membunuh kuman maka akan memenuhi 6,17\% keinginan konsumen sedangkan dengan memperhatikan atribut bentuk oval hanya akan memenuhi 3,25\% keinginan konsumen.

Prioritas perancangan yang akan dilakukan perusahaan adalah dengan memasukkan kelompok atribut mutu mulai dari yang tertinggi (ranking 1 s.d. 19) ke dalam produknya (Ficalora dan Cohen, 1995). Prioritas ini dilakukan mengingat keterbatasan yang biasanya dimiliki perusahaan. Dapat dilihat bahwa dengan memenuhi lima kelompok atribut persyaratan konsumen tertinggi (berkhasiat membunuh kuman/antibakteri, tidak menimbulkan iritasi, berkhasiat mengangkat kotoran, berkhasiat melembabkan kulit, dan mencantumkan registrasi BPOM) maka keinginan konsumen yang akan dicapai sebesar 30,27\%. Jika sepuluh kelompok atribut mutu persyaratan konsumen tertinggi (ranking 1 s.d. 10) dipenuhi maka tingkat keinginan konsumen yang akan dicapai adalah sebesar $63,76 \%$. Kesepuluh atribut mutu tersebut adalah berkhasiat membunuh kuman/antibakteri, tidak menimbulkan iritasi, berkhasiat mengangkat kotoran, berkhasiat melembabkan kulit, mencantumkan registrasi BPOM, kesan kesat, busa yang banyak, mencantumkan registrasi halal MUI, wangi dirasakan saat digunakan/saat mandi, dan tekstur padat. Menurut Sipahutar (2013), ketertarikan terhadap sabun mandi yang berkhasiat mengangkat kotoran dan juga berfungsi sebagai antikuman memiliki faktor tertinggi yang diharapkan konsumen. Atolani et al. (2016) juga menyatakan bahwa nilai yang menentukan kualitas sabun mandi padat meliputi daya bersih sabun, khasiat antiseptik dan kemampuan melembabkan serta melembutkan kulit. 
JTS : Jurnal Teknik

P-ISSN: 2302-8734

E-ISSN: 2581-0006
JT

FT UMT
Vol. 9 No. 2 Th. 2020

Halaman : $44-53$

Desember 2020

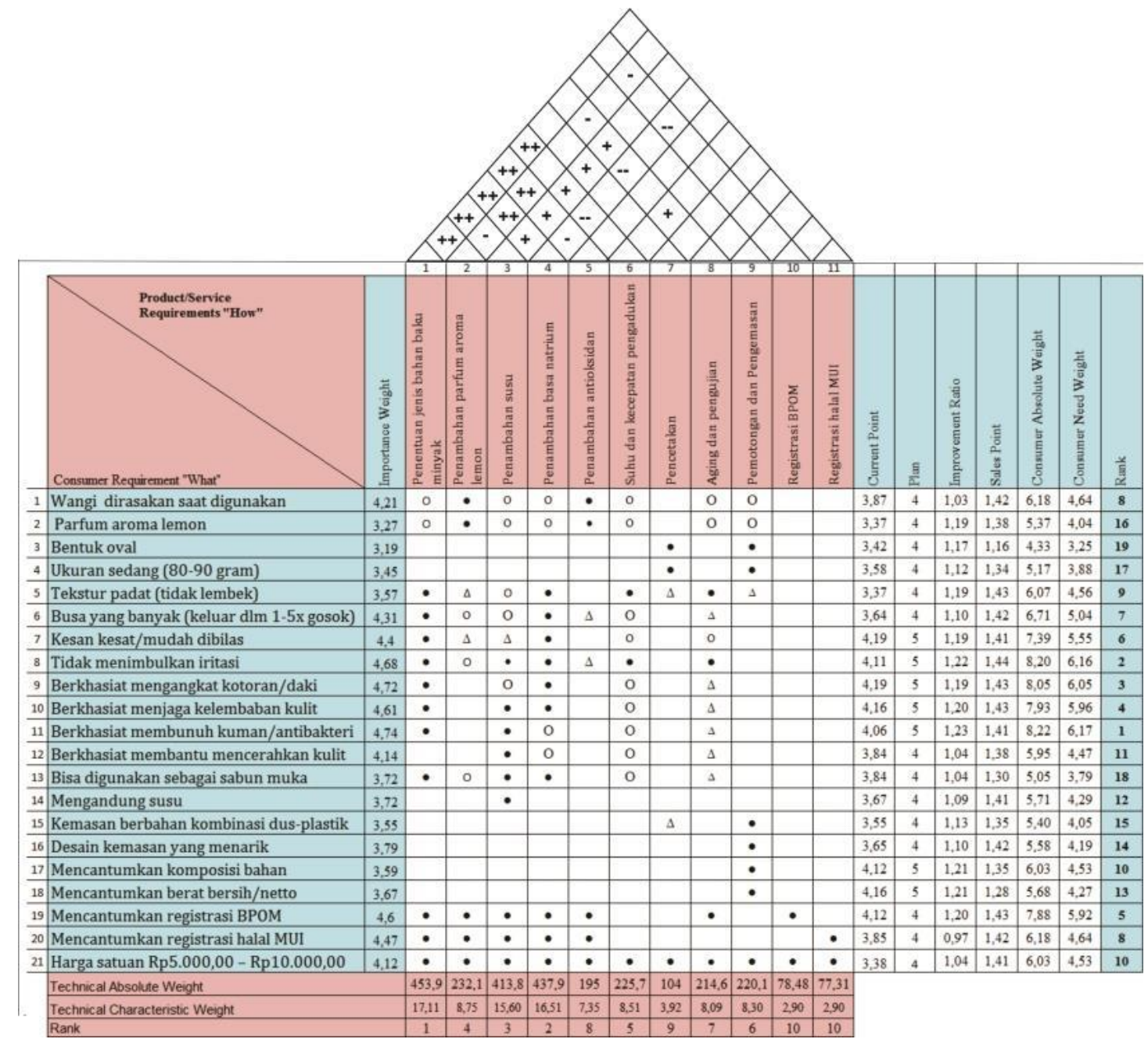

Gambar 1 Skema rumah kualitas untuk rancangan produk sabun mandi padat

Perancangan teknik pembuatan sabun mandi dilakukan berdasarkan analisis rumah mutu (Andayani, et al., 2014). Berdasarkan analisis data yang telah dilakukan, parameter-parameter teknis yang dirancang tergolong menjadi 10 kelompok tingkat prioritas berdasarkan bobot karakteristik teknis. Kolom bobot karakteristik teknik (technical characteristic weight) menunjukkan seberapa besar masing-masing parameter teknis dapat memenuhi keinginan konsumen (Ficalora dan Cohen, 1995). Hal ini bermanfaat bagi perusahaan sebagai informasi dalam menentukan tingkat prioritas dari masing-masing parameter teknis yang akan dilaksanakan. Gambar 1 menunjukkan bahwa penentuan jenis bahan baku minyak memiliki bobot tertinggi yaitu sebesar $17,11 \%$. Parameter registrasi BPOM dan halal MUI memiliki bobot terendah yaitu sebesar 2,90\%. Sehingga dapat disimpulkan dengan memperhatikan penentuan jenis bahan baku minyak maka akan memenuhi $17,11 \%$ keinginan konsumen sedangkan dengan memperhatikan registrasi BPOM, dan halal MUI hanya akan memenuhi 2,90\% keinginan konsumen.

Berdasarkan analisis rumah mutu, prioritas perancangan yang akan dilakukan oleh perusahaan adalah dengan memasukkan parameter teknis mulai dari pertingkat tertinggi (Ficalora dan Cohen, 1995) Prioritas ini dilakukan mengingat keterbatasan yang biasanya dimiliki perusahaan. Penentuan jenis minyak merupakan faktor kritis paling tinggi. Atribut mutu sabun mandi sangat dipengaruhi oleh jenis minyak yang digunakan (Atolani, et al., 2016). Minyak dengan kandungan asam lemak jenuh rantai sedang 
JTS : Jurnal Teknik

P-ISSN: 2302-8734

E-ISSN: 2581-0006

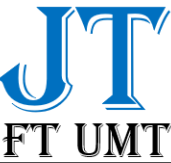

Vol. 9 No. 2 Th. 2020

Halaman : $44-53$

Desember 2020

(minyak kelapa dan VCO) memberikan karakteristik yang cocok untuk memenuhi keinginan konsumen seperti kemampuan mengangkat kotoran, kemampuan membunuh kuman, kemampuan melembabkan, bisa digunakan sebagai sabun muka, kesan kesat, busa yang banyak, serta harga. Analisis rumah mutu juga dapat menunjukkan angka kumulatif bobot keinginan konsumen yang dicapai dengan melakukan prioritas perancangan. Dengan mengembangkan produk sabun mandi padat berdasarkan lima kelompok prioritas tertinggi (ranking 1 s.d.5) maka akan memenuhi $66,47 \%$ keinginan konsumen dan jika mengembangkan berdasarkan sepuluh kelompok prioritas maka akan memenuhi 100\% keinginan konsumen.

\section{Kesimpulan}

\section{KESIMPULAN}

1. Terdapat 21 atribut mutu sabun mandi yang menjadi persyaratan konsumen. Atribut persyaratan konsumen berdasarkan tingkat kepentingan konsumen (importance weight) secara berurutan dari yang tertinggi hingga terendah adalah berkhasiat membunuh kuman/antibakteri, berkhasiat mengangkat kotoran, tidak menimbulkan iritasi, berkhasiat melembabkan kulit, mencantumkan registrasi BPOM, mencantumkan halal MUI, kesan kesat, busa yang banyak, wangi dirasakan saat digunakan/saat mandi, berkhasiat mencerahkan, harga satuan Rp5.000,00 - Rp10.000,00 kemasan isi 80-90 gram, desain kemasan menarik, bisa digunakan sebagai sabun muka, mengandung susu, mencantumkan berat bersih, mencantumkan komposisi, tekstur padat, kemasan berbahan dus dan plastik, ukuran sedang (80-90 gram), parfum aroma lemon, dan bentuk oval.

2. Terdapat sebelas parameter teknis yang menjadi persyaratan teknis pembuatan sabun mandi. Parameter teknis tersebut meliputi penentuan jenis bahan baku minyak, penambahan parfum aroma lemon, penambahan susu, penambahan basa natrium, penambahan antioksidan, suhu dan kecepatan pengadukan, pencetakan, aging dan pengujian, pemotongan dan pengemasan, registrasi BPOM dan registrasi halal MUI.

3. Atribut mutu sabun mandi yang menjadi prioritas tertinggi berdasarkan analisis house of quality adalah berkhasiat mampu membunuh kuman/anti bakteri sedangkan prioritas terendah adalah atribut bentuk oval.

4. Parameter teknis yang menjadi prioritas tertinggi dalam perancangan adalah penentuan jenis bahan baku minyak sedangkan prioritas terendah adalah registrasi BPOM dan MUI.

\section{Saran}

Perancangan sabun mandi yang perlu dilakukan tahap selanjutnya adalah melakukan rancangan formulasi kombinasi minyak, rancangan formulasi penambahan basa, dan rancangan formulasi penambahan susu. Perlu juga dilakukan penelitian lanjutan mengenai pengembangan produk sabun mandi meliputi tahapan pembuatan prototype produk sehingga dapat dilakukan pengujian fisik, kimia dan sensori, serta perhitungan biaya produksinya.

\section{DAFTAR PUSTAKA}

Agero, A.L., dan V. Veralo-Rowell. 2004. A Randomized Double-Blind Controlled Trial Comparing Extra Virgin Coconut Oil With Mineral Oil As A Moisturizer For Mild To Moderate Xerosis. Dermatitis, 15(3): 109-16.

Akao, Y. 2012. The Method for Motivation by Quality Function Deployment (QFD). Nang Yan Business Journal, 1(1): 1-9.

Anastasiadou S. D. 2011. Relialibility and Validity Testing of A New Scale for Mesuring 
Attitudes Toward Learning Statistics with Technology. Acta Didac Napoc. 4 (1): 110.

Andayani, A., Sukardi, dan A. Suryani. 2015. Desain Produk Makanan Ringan untuk Ibu Hamil dengan Menggunakan Quality Function Deployment (QFD). E-Jurnal Agroindustri Indonesia, 4 (1): 244-251.

Arancon, R. N. 2013. Market and Trade of Coconut Products. Makalah presentasi disampaikan dalam Experts Consultation on Coconut Development in Asia and Pasific, Asia and Pasific Coconut Community, Bangkok, 30 Oktober - 1 November 2013.

Atolani, O., E. T. Olabiyi, A. A. Issa, H. T. Azeez, E. G. Onoja, S. O. Ibrahim, M. F. Zubair, O. S. Oguntoye dan G. A. Olatunji. 2016. Green Synthesis and Characterisation of Natural Antiseptic Soaps from The Oils of Underutilised Tropical Seed. Sustainable Chemistry and Pharmacy, 4: 32-39.

Badan Pusat Statistik Kota Tegal. 2016. Statistik Daerah Kota Tegal 2016.

Febriyenti, L. I. S., dan R. Nofita. 2014. Formulasi Sabun Transparan Minyak YlangYlang dan Uji Efektivitas terhadap Bakteri Anti Jerawat. Jurnal Sains Farmasi dan Klinis, 1(1): 61-71.

Fathima, A., S. Varma, P. Jagannath, dan M. Akash. 2011. General Review On Herbal Cosmetics. International Journal of Drug Formulation and Research, 2(5): 140-165.

Ficalora, J. P., dan L. Cohen. 1995. Quality Function Deployment and Six Sigma. Second Edition. United States: Prentice Hall.

Gharakhani D, dan J. Eslami. 2012. Determining Customer Needs Priorities for Improving Service Quality Using QFD. International Econnomic Management Science. 1 (6): 21-28.

Izhar, H. 2010. Analisis Sikap Konsumen terhadap Atribut Sabun Mandi (Studi pada Sabun Mandi Merk Giv dan Lux di Kota Malang). Wacana, 13(4): 615-630.

Jaiswal, E. S. 2012. A Case Study on Quality Function Deployment (QFD). IOSR J Mech Civ Eng. 3 (6): 27-35.

Kasor, F. dan A. Sukmawati. 2015. Pengaruh Penggunaan Virgin Coconut Oil (VCO) sebagai Emolient terhadap Sifat Fisik dan Stabilitas Vitamin C dalam Sabun Transparan. Naskah Publikasi Surakarta: Universitas Muhamadiyah Surakarta.

Kim, H. Y. dan J. E. Chung. 2011. Consumer Purchase Intention for Organic Personal Care Products. Journal of Consumer Marketing 28(1): 40-47.

Riduwan. 2004. Metode dan Teknik Menyusun Tesis. Bandung: Alfabeta.

Salim, O. K. 2014. Pengembangan Produk Emeron dengan Metode Quality Function Deployment (QFD). [Tesis]. Yogyakarta: Fakultas Ekonomi dan Bisnis, Universitas Gadjah Mada.

Setyoningrum, E. N. M. 2010. Optimasi Formula Sabun Transparan dengan Fase Minyak Virgin Coconut Oil dan Surfaktan Cocoamidopropyl Bethaine: Aplikasi Desain Faktorial. [Skipsi]. Yogyakarta: Universitas Sanata Dharma.

Sipahutar, D. M., R. P. Bangun, dan U. Sinulingga. 2013. Analisis faktor Ketertarikan Mahasiswa terhadap Produk Sabun Mandi. Jurnal Saintia Matematika 1(2): 175185.

Sugiyono. 2008. Metode Penelitian Kuantitatif, Kualitatif dan R\&D. Bandung: Alfabeta.

Walpole RE. 1992. Pengantar Statistik. Jakarta: Gramedia.

Widyasanti, A. dan A. H. Hasna. 2016. Kajian Pembuatan Sabun Padat Transparan Basis Minyak Kelapa Murni dengan Penambahan Bahan Aktif Ekstrak Teh Putih. Jurnal Penelitian Teh dan Kina, 19(2): 179 - 195. 